\title{
Entrepreneurial Measurement Modelfor Teacher Education
}

\author{
MohdAsri Ispal $^{1}$, MohdKhata Jabor ${ }^{2}$ \\ ${ }^{1,2}$ Universiti Teknologi MalaysiaSkudai, Johor, MALAYSIA
}

\begin{abstract}
The definition of entrepreneurship transcends multi disciplines and not only limited to the profitmaking business entities. Within the teachers' education field, entrepreneurship is viewed as a critical component in the process of preparing the competent and skilled teachers in handling the present challenging education environment. This research intends to develop the instrument which can be used in the assessment of the students of Institute of Teachers Education Malaysia towards the identification of their entrepreneurship traits. The domains of entrepreneurship will be explored through the relevant literature review and the expert's opinion as well. In this research, the expert's opinion using four rounds of Delphi Technique is employed to determine and verify the suitability of the elements of entrepreneurship with the teacher's education. The panel of experts selected in the Delphi Technique consists of the practicing entrepreneurs and experts from various public higher learning institutions. There will be twelve experienced expert panels both from the entrepreneurship and teachers education involved in this research activity. The instrument (measurement model) will be developed based on the entrepreneurship elements which have been initially designed. Statistical analysis, structural equation modelling using Confirmatory Factor Analysis will be used to test, modify and to confirm the suitability of the items towards the construct/entrepreneurship elements and fit of the model simultaneously.
\end{abstract}

Keywords: Entrepreneurship, instrument development, Delphi Technique, teacher education

\section{Introduction}

In accordance with desire become a leading country progress based on knowledge and innovation, Malaysia ranked technology-based importance of development competency, innovation, creativity and entrepreneurship as priority. Therefore, higher education institutions, including Institute of Teachers Education Malaysia (IPG) given a role as a place for students who can contribute to shaping and positive lifestyle, educated and excellent. Main agenda in producing outstanding individual is entrepreneurial value application in life.

Entrepreneurship in education has gain attention recently (Wei-Loon et al., 2012; Dam et al., 2010).Integrating entrepreneurship elements in teacher's education are viewed as an effective way to enhance the quality of teacher (ZaidatolAkmaliah\&Bagheri, 2011; Dam et al., 2010; Pittaway\& Hannon, 2008). In teacher's education, entrepreneurship element are seen as one needs that are needed to be mastered by students to face challenge as well as needs in educations in today's generation. (Boyles \& Collage, 2012; ZaidatolAkmaliah\&Bagheri 2011: Dam et al., 2010 ). On the awareness to provides future teachers with knowledge, attitude as well as entrepreneurship skills, variaties of curriculum and co-curriculum that leads to element applications and entrepreneurship cultures has been implemented. During the teachers training, the future teachers are not only provided with pedagogy knowledge but also with particularly soft skills and entrepreneurship as manage, lead, effective communication effective, able to solved problems as well as having high work ethics.

\section{Review Of Literature}

Seminal theories in the field of entrepreneurship (e.g.,Kirzner, 1979; McClelland, 1967; Schumpeter, 1942) and recent research (e.g., Boyles \& College, 2012; Azevedo et al., 2012; Martin et al., 2011; Dam et al., 2010; Nor Aishah, 2002) will be used as basic in developing constructs and measurement instruments ofentrepreneurial elements for teacher education.

\section{Entrepreneurship education defined}

Entrepreneurship education defined as a lifelong process to get knowledge, skill and entrepreneurial value through learning being formal or not formal (Nor Aishah, 2002). Nevertheless, do not have agreement on definition education entrepreneurship (Pretorius et al., 2005; Henry et al., 2003; Jones \& English, 2004; Vesper, 1993; Kaufmann \&Dant, 1988). Diversity of definition entrepreneurship education is as a result of ambiguity entrepreneurship concept (Gorman et al., 1996; Jack\& Anderson, 1999). Therefore, Rushing (1990) does not use these definitions, but emphasised that entrepreneurship education cannot use be on one perspective because entrepreneurial field is a dynamic process (Garavan\&Cinneide, 1994; Gorman, 1996; Venkataraman, 2002). 
Rabbior (1990) defines entrepreneurial education as a creative change process. Therefore this entrepreneurship education should not targeted only to producesuccessful entrepreneur but to produce a generation that is creative, innovative, dare to take risk and can adaptive oneself with change and will succeed in all their effort. entrepreneurshipeducationhave to concentrate on to obstacle elimination self confidence and selfesteem in each student. Due to this, entrepreneurial definition education explicable as education which developed individual with features and entrepreneurial ability, creating awareness on creative creation, knowledge and entrepreneurial skills whether make business or not. In conclusion, entrepreneurial education can create attitude, giving knowledge, skill and competency entrepreneurship (Dana, 2001; Henry et al., 2003).

\section{Model of Entrepreneurship education}

In developing teacher's education entrepreneurial measurement model, a few of the entrepreneurial education model which related are considered as a guideline.

\section{Entrepreneurial performance education model (E/P model)}

The E/PModel are used as a guide in developing the curriculum and syllabus of entrepreneurship education (Pretorius et al., 2005). The model shows a direct linear that entrepreneurial performance is a function of motivation, entrepreneurial skills and business skills and can be described in the linear equation:

$\mathrm{E} / \mathrm{P}=f[\mathrm{aM}(\mathrm{bEcB} / \mathrm{S})]$

Where: E/Pisthe Entrepreneurial Performance; M isthe Motivation; E/Sisthe Entrepreneurship skills; B/Sisthe Business Skills; and, Cis the Constants.

Based on the E/P Model, entrepreneurial education programs can be designed based on three constructs of motivation, entrepreneurial skills and business skills. Motivation refers to internal control, perseverance, endurance, leadership and decisiveness. Entrepreneurial skills include creativity, risk-taking and to identify opportunities. Business skills involves the skills such as to administer and to manage the affairs of business, finance, marketing, operations, human resources, legal, communications as well as business planning.

\section{Life Long Learning Model}

Life long learning model was submitted by Ashmore (1990) explains the role of entrepreneurship education in the various stages of life. The first step is to learn the basic knowledge economy up. Students need to be exposed to entrepreneurship and to the problems faced by entrepreneurs. At this level of awareness of entrepreneurship as a career option should be used.

At the third level are creative applications for students to generate creative ideas unique business. Furthermore, they provide the business plan as first step. It is important for students to learn the process of starting a business. In this model also explained that students need to get the experiences of working and training and education as a preparation on becoming a successful entrepreneur. The fourth stage is the establishment of eventual business. Prospective entrepreneurs need short-term training and other supports that will help solve business problems to be faced. The final stage in this model is businesses that require effective management.

According to Nor Aishah (2002), the elements of entrepreneurship education are based on four main pillars of attitude formation, the formation of thinking, management skills and vocational formation. Teaching and learning activities under the domain formation of attitudes should give entrepreneurs exposure, motivation and the development of entrepreneurial characteristics. The domain of entrepreneurial mindset give creativity, innovation, generating new ideas and to identify opportunities. Domain basic business management skills preparing them to enter into business and continued their career as an entrepreneur. Vocational formation includes the formation of attitudes, thoughts, skills and knowledge in various fields.

Other factors that are also needed to be considered that are successful entrepreneur characteristics. Some of the characteristics of successful entrepreneurship are creative and inovation, initiative, ethics, Information Communication and Technology literacy, work team, networking skills, career adaptability, influence, leadership, communication skills and problem solving skills (Boyles \& Collage, 2012; Azevedo et al., 2012; Martin et al., 2011;Dam et al., 2010).

\section{Statement Of The Problem}

In the structure of Bachelor of Teaching (PISMP), one of the learning outcomes to be is to ensure that students can apply their knowledge and entrepreneurial skills and apply them in their daily lives (BahagianPendidikan Guru, 2010). However, the Program Structure are not explained in detail what are the elements of entrepreneurial skills to students and it is controlled by just a general guideline only. In the structure of the program also not clearly stated how each element of competency is measured and evaluated. 
Entrepreneurial competence needs teacher has to be able to make future teachers who were born shows the behavior as a successful entrepreneur.

MohdAsri\&MohdKhata (2012) found, the personal entrepreneurial competencies of students PISMP is still in moderate level and this gives the impression that there are gaps which needed to improve work practices such as creativity, innovative thinking and initiative. Entrepreneurial competency levels will invite problems rather modest in the current educational challenges (Norasmah\&Rasmuna, 2012; ZaidatolAkmaliah\&Bagheri, 2011; Sarimah et al., 2010; Pittaway\& Hannon, 2008; Abd. Rahim et al., 2001). Teachers should be able to master the competencies required as a basis for effectiveness of teaching and learning (Pantic\&Wubbels, 2010; Chee, 2008). Therefore, a model of entrepreneurial measurement are relevant to teacher education will need to be eveloped to roduce innovative and competence teachers.

\section{Purpose Of The Study}

This concept paper discusses the elements of entrepreneurial ventures that fit in teacher's education at the IPG. IPG is a teacher education institution that aims to produce students (future teachers) quality, competent, competitive and able to cope with the current educational challenges.

The main purpose of this research is to identify the constructs of entrepreneurial elements appropriate to the particular needs of teacher education at the Institute of Teacher Education. Constructs of entrepreneurial elements identified will be used to form the frame of the measurement model for each complete mastery of the competency construct. Therefore, this research is important in identifying the level of the students who were produced by the Institute of Teacher Education in Malaysia against the required competencies before they are employed as a teacher, forming the identity of the teacher, competent, innovative and able to meet the challenges of contemporary education.

Entrepreneurial competency model developed teacher education can stimulate creativity and innovative thinking among students (Louvenco\&Jaywarna, 2010; Pittaway et al., 2009). Standards outlined in this entrepreneurial competency requires students to master the dimensions of the personal qualities include creativity, innovative thinking and teamwork. Creativity and innovative thinking are the elements that need to be established among future teachers to improve the quality of education when they were deployed to work in schools in the future.

Another purpose of this study is to develop the measurement instrument that will be used to measure the level of entrepreneurship competencies in determining and tracking standards that the students of the Institute of Teacher Education competencies outlined.Soon produced instruments can also be used by other institutes of higher learning such as universities or colleges that train prospective teachers. Instruments developed not limited usefulness in Teacher Education Institute but it can be extended for use in other educational institutes.

\section{Research Method}

\section{Methodology}

1. Delphi Technique : In order to avoid having a few experts affecting the thinking of other participants, and to have a preliminary understanding of the entrepreneurial competencies of teacher education students, the competence indicator categories were sent to a panel of experts to verify the necessity of these competences and collect feedback for revisions.

2. Instrument Development: measurement instrument to be developed based on the constructs that were formed in the first round Delphi technique. In the second round, a panel of experts will determine the level of their agreement to the statements in the instrument. This process will continue until four laps or researchers already feel that the objective has been achieved. Items used by Abd. Rahim et al. (2001) and the Malaysian Youth Entrepreneurship Index (Norasmah\&Halimah, 2007)will be used as a guide in the construction of this instrument.

3. Factor Analysis: will be used to test, modify and to confirm the suitability of the items towards the construct/entrepreneurship elements and fit of the model simultaneously.

\section{Research Participant}

The participants in the Delphi Technique are experts in teacher education, entrepreneurship education and entrepreneurial practioners. A total of 12 experts were involve as expert panel.Participants consisted of Institute of Teachers Education Malaysia anduniversity lecturers experience in entrepreneurship and teacher education. Entrepreneurs who have been successful as well as a panel of experts will be involved in this study to obtain the actual input through the experience they have gain as entrepreneurs who have been successful.

\section{Discussion}

For the purpose of discussion, only a few elements will be discussed. 


\section{Inventive thinking}

Element of "inventive thinking" involves thinking related to something new, analysis, comparison interpretation, evaluation and synthesis to develop new solutions to complex problems (Boyles \& College, 2012; Lemke et. al., 2003).A person who owns inventive thinking can help drive towards maximizing the use of available resources and knowledge and raise positive change. Elements in "inventive thinking" is creativity and innovative thinking, curiosity and risk-taking, high order thinking and sound reasoning. Creativity and innovative thinking refers to a person's efforts in solving problems with considering new perspectives (Amabile, 1996) and relation to entrepreneurship (Rauch \&Frese, 2000; Timmons, 1994). It will give value added to a service and product/result. In the context of teacher education, creativity and innovative thinking has a very close related in relationship with the formation of positive attitudes.

Risk management refers to the identification, evaluation, and how to manage the risk of interest followed by efficient use of resources to control and reduce the possibility of unwanted things. Risk may come from various sources such as economic uncertainty, changes in policies, failures, accidents and destinies. The ability to control and manage risk is a strength that allows one successful entrepreneur (Dam et al., 2010). In education, risk management skills are essential to ensure the effectiveness of action, strategy and approach taken by teachers in teaching and learning and the management in schools.

\section{Communication}

Elements of "communication" to emphasize the development of social skills to solve problems, innovate and manage emotions and communicate (Boyles \& College, 2012; Lemke et al., 2003). Relations with other individuals important in ensuring the success of entrepreneurial activity.This fundamental relationship to the formation of social capital and open up opportunities to start something new. In the context of education, Byers (1997) suggests entrepreneurship education should emphasize the social processes and social behaviour.Elements in "communication" is teamwork and collaboration, social and cross-cultural skills and networking.

Networking skills refer to a person's competence in building and maintaining relationships with other people or organizations to help achieve the desired goal (Forett\&Dougherry, 2001). Social network consists of the internal network and external network.Networking that are involving the relations between students with campus's friends as well as realtions with the lectures in the same campus. External network involving student relationships with external parties such as education officer at the District Education Office, school and relationships with students at other campuses. As someone who was thought as successful entrepreneurs, students (future teachers) needed to have a good network skills with other individuals within the organization and outside the organization. Highlights of the study found, networking skills have something to do with the success of entrepreneurial activities (Baron \&Markman, 2003).

\section{Conclusion}

This concept paper proposes the study of the identification of an appropriate entrepreneurial competence construct in teacher education especially for students who are involved in the Bachelor of Teaching program at the Institute of Teacher Training. This concept paper also aims to provide space for research to develop assessment instruments that will be used in measuring the level of entrepreneurial competencies in teacher education.

Impact of entrepreneurial elements in the organization to improve employee satisfaction, create and improve performance (Safari et al., 2012; Barney, 2010; Semler\& Chin, 2004; Byham\& Moyer, 2002).Entrepreneurial elements is a complete package that combines the values, knowledge, skills and personality traits that can make a positive impact in the organization. This entire element will lead to the formation of entrepreneurship in soul competency of teachers and able to master a variety of skills not only able to teach it well, but also has retained a convincing self, stick to the principle of diligent work, and wisely put themselves in the school community.

\section{References}

[1]. Abd. Rahim Bakar, ZaidatolAkmaliah Lope Pihie, Mohd. Majid Konting\& Genevieve KlangAngking. (2001). The Perceived Entrepreneurial Characteristics of Malaysian Living Skill Teachers: Implication for Teacher Preparation Programme. Pertanica J. Soc. Sci. \& Hum. 9(2) pp 123-129

[2]. Ashmore, M.C. (1990). Entrepreneurshipin vocational education.InCalvin.A Kent.

[3]. Entrepreneurship Education: Current Development, Future Direction. New York: Quorum Books.

[4]. Azevedo, A., Apfelthaler, G., \& Hurst, D. (2012). Competency development in business graduates:an industry-driven approach for examining the alignment of undergraduate business aducation with industry requirement. The International Journal of Management Education. 10. pp 12-28.

[5]. BahagianPendidikan Guru.(2010). BukuPanduan Program IjazahSarjanaMudaPerguruanInstitutPendidikan Guru Malaysia.KementerianPendidikan Malaysia.

[6]. Barney, J.A. (2010). Firm resources and sustained competitive advantage. Journal of Management.19(1), pp 99-120. 
[7]. Baron, R.A. \&Markman, G.D. (2003). Beyond social capital: the role of entrepreneur socialcompetence in their financial success. Journal of Business Venturing. 18, pp 41-60.

[8]. Boyles, T. \& College, M. (2012).21st century knowledge, skills, and abilities and entrepreneurialcompetencies: A model for undergraduate entrepreneurship education. Journal of Entrepreneurship Education. 15, pp 41-55.

[9]. Byham, W. \& Moyer, R. (2002).Using Competencies to Build a Successful Organization.Canada:DDL.

[10]. Byres, T., Kist, H., \& Sutton, R. (1997). Characteristics of the Entrepreneur: Social Creatures, NotSolo Heroes.In R. C. Dorf.The Handbook of Technology Management. Boca Raton:CRC Press LLC.

[11]. Chee Kim Mang. (2008). Kualiti guru permulaankeluaransebuah institute perguruan :satutinjauandariperspektifpentadbirsekolah. JurnalPendidikdanPendidikan. 23, pp 49-67

[12]. Dam, K.V., Schipper, M., \&Runhaar, P. (2010). Developing a competency-based framework forteachers' entrepreneurial behavior. Teaching and Teacher Education. 26,pp965-971.

[13]. Dana, L. (2001). The education and training of entrepreneurs in Asia.Education \& Training. 43, pp405-416.

[14]. Forett, M.L., \&Dougherry, T.W. (2001). Correlates of networking behavior for managerial andprofessional employees. Group and Organization Management. 26, pp 283-311.

[15]. Garavan, T.N. \&Cinneide, B.O. (1994). Entrepreneurship education and training programmes: Areview and evaluation. Journal of European Industrial and Training. 18(8), pp 3-13.

[16]. Gorman, G., Hanlon, D. \& King, W. (1996). Some research perspectives on entrepreneurshipeducation, enterprise education and education for small business management: A ten year literature review. International Small Business Journal. 15(3), pp 56-77.

[17]. Henry, C., Hill, F., \& Leitch, C. (2003).Entrepreneurship Education and Training.Aldershot:Ashgate.Jack, S.L. \& Anderson, A.R. (1999).Enrepreneurship education within enterprise culture producingreflective practitioner. International Journal of Entrepreneurial Behaviour\& Research. 5(3), pp 110-121.

[18]. Jones, C. \& English, J. (1994).A contemporary approach to entrepreneurship education.Educationand Training. 46(8), pp 416-423.

[19]. Kirzner, I.M. (1979). Perception, Opportunity, and Profit: Studies in the theory of entrepreneurship.Chicago: University of Chicago Press.

[20]. Lemke, C., Coughlin, E., Thadani, D.V.,\& Martin, C. (2003).enGauge $21^{\text {st }}$ Century Skills: Literacyin the Digital Age. Los Angeles: Metiri Group.

[21]. Louvenco, F. \&Jayawarna, D. (2011). Enterprise education: the effect of creativity on trainingoutcomes. International Journal of Entrepreneurial Bahaviour\& Research. 17(3), pp 224-244.

[22]. McClelland, D.C. (1987), Characteristics of successful entrepreneurs, The Journal of CreativeBehavior, 21(3), pp. 219-33.

[23]. Mohd.AsriIspal\&Mohd.KhataJabor. (2012). An analysis of the personal entrepreneurialcompetencies of Malaysian Teachers Education Institute students: Implication for teacher preparation program. IPGM International Convention in Teacher Learning and Development (IICTLD). Kuala Lumpur 19 - 21 November 2012.

[24]. Nor AishahBuang.(2002). AsasKeusahawanan. Selangor: PenerbitFajarBakti.

[25]. NorasmahOthman \&Halimah Harun.(2007). KeusahawananRemajaMalaysia.Serdang :Universiti Putra Malaysia.

[26]. Norasmah Othman\&Rasmuna Hussain. (2012). Evaluation of the implementation of the ModuleBasic of Entrepreneurship in College Community Ministry of Higher Education.2nd International Conference on Economics, Trade and Development IPEDR. 36. pp 96-100.

[27]. Pantic, N. \&Wubbels,T. (2010). Teacher competencies as a basic for teacher education-view ofSerbian teachers and teacher educators. Teaching and Teacher Education. 26, pp 694-703.

[28]. Pittaway, L., \& Hannon, P. (2008). Institutional strategies for developing enterprise education: Areview of some concepts and models. Journal of Small Business and Enterprise.15(1), pp 202-226.

[29]. Pittaway, L., Hannon, P., Gibb, A. \& Thomson, J. (2009). Assessment practice in enterpriseeducation. International Journal of Entrepreneurial Bahaviour\& Research. 15(1), pp 71-93.

[30]. Pretorius, M., Nieman, G., \&Vuuren, J. (2005). Critical evaluation of two models forentrepreneurial education: an improved model through integration. International Journal of Educational Management.19(5). pp 423-427.

[31]. Rabbior, G. (1990). Elements of a successful entrepreneurship/economics/education program. InCalvin.A. Kent. Entrepreneurship Education: Current Development, Future Direction. New York: Quorum Books.

[32]. Rushing, W.F. (2001). Entrepreneurship and education.InCalvin.A. Kent. EntrepreneurshipEducation: Current Development, Future Direction. New York: Quorum Books.

[33]. Safari, S., Khalilzade, M., \&Mobaraki, M.H. (2012).Idendifying the entrepreneurshipcompetencies effectiveness in commercialization of technology: a case study of nanotechnology business. International Journal of Business Economic and Management Research. 2(7), pp 19-30.

[34]. SarimahChe Hassan, NorlizahChe Hassan \&NorAishahBuang. (2010). Penguasaankemahiraninsaniah (kemahirankeusahawanan) dalamkalangan guru sekolah di Malaysia. Proceedings of the 4th International Conference on Teacher Education: Join Conference UPI \& UPSI, Bandung, Indonesi, 8-10 Nov. 2010.

[35]. Semler, J., \& Chin, R. (2004).A framework for developing HR executives in Hong Kong. HumanResources Competencies. 39, pp 324-336.

[36]. Venkataraman, S. (2002).The distinctive domain of entrepreneurship research.In S. Shane. TheFoundation of Entrepreneurship. Cheltenham: Edward Elgar.

[37]. Vesper, K. (1993).Entrepreneurship Education. Los Angeles: University of California.

[38]. Wei-Loon Koe, Juan Rizal Sa'ari, Izaidin Abdul Majid, \&Kamariah Ismail. (2012). Determinantsof entrepreneurial intention among millennial generation. Procedia-Social and Behavioral Science. 40, pp 197-208.

[39]. ZaidatolAkmaliah Lope Pilie\&Bagheri, A. (2011). Teachers' and students' entrepreneurial self-efficacy: Implication for effective teaching practice. Procedia-Social and Behavioral Sciences. 29. pp 1071-1080 